Kaestner, Roland/Kessler, Andreas (Eds.), 2008: Innere und Äußere Sicherheit. Workshop-Bericht, Strausberg.

Krause, Keith, 2007: Towards a Practical Human Security Agenda, DCAF: Policy Paper No. 26, Geneva.

Kümmel, Gerhard, 2005: Auftrag und Aufgaben des Militärs im Wandel, in: Nina Leonhard/Ines-Jacqueline Werkner (Eds.), Militärsoziologie - Eine Einführung, Wiesbaden, 50-67.

Locke, John, 2000 [1690]: Two Treatises of Government, ed. by Peter Laslett, Cambridge.

Middel, Stefan, 2007: Innere Sicherheit und präventive Terrorismusbekämpfung, Baden-Baden.

Münkler, Herfried, 2008: Krieg, in: Erwägen - Wissen - Ethik 19 (1), 27-43.

Nolte, Georg/Krieger, Heike, 2002: Europäische Wehrrechtssysteme, Baden-Baden.
Reinhard, Wolfgang, 1999: Geschichte der Staatsgewalt. Eine vergleichende Verfassungsgeschichte Europas von den Anfängen bis zur Gegenwart, München.

Rotter, Manfred, 2003: Neue Herausforderungen und Risiken für Sicherheitspolitik, in: Jörg Calließ (Ed.), Die Verflochtenheit und Verflechtung von äußerer und innerer Sicherheit, Loccumer Protokolle 55/03, Rehburg-Loccum, 71-84.

Schmidt-Radefeldt, Roman, 2004: Homeland Security durch Streitkräfte: Verfassungsrechtliche Rahmenbedingungen für innereuropäische Militäreinsätze, in: Heiko Borchert (Ed.), Weniger Souveränität - Mehr Sicherheit. Schutz der Heimat im Informationszeitalter und die Rolle der Streitkräfte, Hamburg/Berlin/Bonn, 76-94.

Werkner, Ines-Jacqueline, 2006: Wehrpflicht oder Freiwilligenarmee? Wehrstrukturentscheidungen im europäischen Vergleich, Frankfurt a. M.

\title{
Conceptualising Non-traditional Roles and Tasks of Armed Forces
}

\author{
Albrecht Schnabel and Danail Hristov*
}

\begin{abstract}
Armed forces around the world are involved in non-traditional roles and tasks beyond their core competence of defending the state from external threats. Evolving non-traditional tasks include international, domestic, military and non-military ones, both independently and subsidiary to other security institutions' activities. Considerable variation exists across countries in the development, scope and nature of such non-traditional roles. This article presents a conceptual framework in order to allow comparative analyses of evolving non-traditional roles of armed forces. Focusing primarily on international and domestic roles as entry points to a discussion of non-traditional roles, it further illustrates the utility of this conceptual framework by drawing on a number of selected armed forces in established democracies in Western Europe, setting the stage for further analysis of the motivations, opportunities, risks and implications of evolving non-traditional roles and tasks.
\end{abstract}

Key words: Armed forces, non-traditional roles, subsidiary roles, peacekeeping, security sector Streitkräfte, nicht-traditionelle Rollen, Friedenserhaltung, Unterstützungsrollen, Sicherheitssektor

\section{Introduction}

$\mathrm{T}$ The end of the Cold War two decades ago has created new international realities, along with expectations for a sizeable peace dividend. However, newly emerging security challenges and interpretations of what should be considered suitable tasks and roles of armed forces have characterised what some observers call "profound ... shifts in their core roles ... [which are] ... increasingly challenging long-

\footnotetext{
Dr. Albrecht Schnabel is a Senior Fellow, Danail Hristov is a Research Assistant at the Research Division of the Geneva Centre for the Democratic Control of Armed Forces (DCAF). Both currently work on a comparative analysis of evolving non-traditional and subsidiary roles of armed forces, funded by the Directorate for Security and Defence Policy of the Swiss Federal Department of Defence, Civil Protection and Sports. The authors thank Ina Amann for research assistance in the preparation of this article.
}

held assumptions about what armed forces are for and how they should be structured and organized."1 Governments and societies have been contemplating newly defined purposes for their armed forces, multiple-task roles beyond the confines of their core function of national defence, the traditional raison d'être of a state's armed forces. This includes the assignments of a variety of international, domestic, military, non-military, as well as subsidiary and non-subsidiary roles and tasks, which has raised questions about the nature, legitimacy and utility of such roles, as well as the interests and motivations of key stakeholders in government, society, and within the country's security sector. Different countries have developed their

1 Timothy Edmunds, "What are armed forces for? The changing nature of military roles in Europe", International Affairs, Vol. 82, No. 6, 2006, p. 1059. 
specific approaches and justifications for such non-traditional roles. Those that evolved in a number of Western European countries shall serve as illustrations for the broader discussions introduced in this article.

For the purpose of this examination, 'non-traditional' roles of armed forces are defined as those that go beyond the "traditional core functional imperative of the defence of the state from external threat." ${ }^{2}$ According to Edmunds, non-traditional roles include "a number of 'new' or at least newly re-emphasized tasks." ${ }^{3}$ He further argues that, although "geographically and historically, the centralization of state security provision is the exception rather than the rule" and interstate conflicts between regular armed forces are almost a Cold War anomaly, those are the main security challenges to which traditional functions of armed forces are originally meant to respond. ${ }^{4}$

Yet armed forces around the world have long served purposes that exceed their traditional core role of defending the state from external threats. Other, non-traditional tasks include changing international and domestic roles, military and nonmilitary tasks, either independently or subsidiary of other security institutions' activities. Considerable variation exists across countries in the development of such non-traditional roles. Focussing on background research (comparative case study analysis) on defence reform and relevant academic, military, political and public debates, this article presents and applies a conceptual framework that allows a comparative analysis of evolving non-traditional roles of armed forces. It further illustrates the utility of this conceptual framework by drawing on a number of selected armed forces in established democracies in Europe, setting the stage for future research into the comparative analysis of states', populations' and armed forces' motivations for engaging in non-traditional tasks as well as the underlying legal and political interpretations and justifications. The article concludes with a brief discussion of the analytical potential of a systematic analysis of comparative information on armed forces' non-traditional roles; its utility in examining contradictions and inconsistencies between legitimacy, practice and utility of those new roles and the tasks of other security institutions, as well as its relevance for the analysis of armed forces beyond the context of established and stable European democracies.

\section{New challenges, new roles for armed forces?}

The end of the Cold War has triggered new security threats, which challenged the traditional roles assumed by armed forces. During the Cold War the main priority of security provision in the Euro-Atlantic area was the search for the most appropriate response to a broad spectrum of military, ideological, political, social and economic challenges from the Soviet Union. Under the pressure of the ensuing nuclear arms race this initially wide conceptualisation was narrowed down to a largely military focus - and thus national and regional security provision became a prime task of states' armed forces and the military

2 Ibid., p. 1062.

3 Ibid.

4 Ibid. strategies of individual states and their security alliances. The Cold War offered a substantial and identifiable military threat, providing the rationale for military organization, heavy weaponry and defence spending. Moreover, conflict occurred primarily between states, which required adequately armed military forces to deter a specific enemy and fight in a war if needed. It encouraged a particular type of force structure that, in the event of an East-West clash, could face up to equivalent opponents in direct military confrontations.

After the likelihood of war between East and West had faded away, predominant realist assumptions about the primacy of military security became questionable and the concept of security expanded to include a broader variety of threats (such as environmental or economic threats). The concept also gained in depth, as the Cold War focus on national security gave way to a more succinct understanding of security needs beyond the individual state (at the regional and international levels) as well as below the state (at the level of communities and individuals). ${ }^{5}$ 'Deterrence' took on a different meaning: Human rights provision assured human security; development assistance supported economic security; long-term investments in environmental protection facilitated long-term environmental security; the alleviation of poverty became viewed as a strategy to prevent violent, community-based conflict; and international cooperation became increasingly viewed as the most effective approach to the prevention of inter-state and intra-state conflict and a plethora of new security challenges, above all the growing fear of global terrorism.

The end of the Cold War was accompanied by widespread societal and political expectations for a considerable peace dividend, which carried consequences for states' armed forces, including calls for the downsizing of armed forces and decreased military and defence spending. As Timothy Edmunds puts it so aptly, first, "the end of the Cold War removed the dominant strategic lens through which armed forces were developed and understood, and has entailed a fundamental reconsideration of their purpose and the bases for legitimacy across the [European] continent." 6 This has triggered wideranging defence reviews, significant cuts in military budgets and societal scrutiny of the armed forces' roles, tasks and purposes. ${ }^{7}$ Second, particularly in the wake of the dissolution of the former Yugoslavia, the traditional roles of armed forces have been challenged in the context of ethnic and civil conflict, both in terms of the roles of armed forces as conflict parties and in terms of the involvement of external armed forces in the form of international peace operations. Third, the terrorist attacks of 9/11 have "reinforced existing pressures towards the development of expeditionary capabilities in reforming armed forces... [which are] ...illustrative of the emerging dominance of Anglo-American concepts of military professionalization in the wider security sector reform area" as well as counter-insurgency and internal security tasks of armed forces. ${ }^{8}$ The focus on the

\footnotetext{
5 See Barry Buzan, "Rethinking Security after the Cold War", Cooperation and Conflict, Vol. 32, No. 1, 1997, p. 6.

6 Edmunds, p. 1062.

7 Ibid. See also Samuel Huntington, "New Contingencies, Old Roles", Joint Force Quarterly, Spring 2003, available at: <http://findarticles.com/p/articles/ mi_m0KNN/is_34/ai_113052670>.

8 Ibid., p. 1063.
} 
Table 1: Matrix of non-traditional roles and tasks of armed forces (country-specific data which allows comparative analyses between any two or more countries) ${ }^{9}$

\begin{tabular}{|c|c|c|c|c|c|c|c|}
\hline $\begin{array}{l}\text { COUNTRY } \\
\text { NAME } \\
\text { (Date of } \\
\text { Analysis) }\end{array}$ & & & & & & & \\
\hline $\begin{array}{l}\text { Evolving } \\
\text { Non-tra- } \\
\text { ditional } \\
\text { Roles/Tasks } \\
\text { (beyond } \\
\text { national } \\
\text { defence) }\end{array}$ & $\begin{array}{l}\text { Definition } \\
\& \text { Nature of } \\
\text { Roles/Tasks }\end{array}$ & $\begin{array}{l}\text { Legitimacy } \\
\& \text { Legal } \\
\text { Basis }\end{array}$ & $\begin{array}{l}\text { Purpose \& } \\
\text { Utility for } \\
\text { Key Stake- } \\
\text { holders }\end{array}$ & $\begin{array}{l}\text { Interests \& } \\
\text { Motivations } \\
\text { of Key Stake- } \\
\text { holders }\end{array}$ & $\begin{array}{l}\text { Impact on } \\
\text { Accoun- } \\
\text { tability, } \\
\text { Objectives, } \\
\text { Command, } \\
\text { Traditional } \\
\text { Roles }\end{array}$ & $\begin{array}{l}\text { Competiti- } \\
\text { on within } \\
\text { Security Sec- } \\
\text { tor (Police, } \\
\text { Paramilitary } \\
\text { Forces, } \\
\text { PMSCs }{ }^{10} \& \\
\text { others) }\end{array}$ & Opportunities \& Threats \\
\hline $\begin{array}{l}\text { Internatio- } \\
\text { nal Roles/ } \\
\text { Tasks }\end{array}$ & & & & & & & \\
\hline $\begin{array}{l}\text { Domestic } \\
\text { Roles/Tasks }\end{array}$ & & & & & & & \\
\hline $\begin{array}{l}\text { Military } \\
\text { Roles/Tasks }\end{array}$ & & & & & & & \\
\hline $\begin{array}{l}\text { Non-milita- } \\
\text { ry Roles/ } \\
\text { Tasks }\end{array}$ & & & & & & & \\
\hline $\begin{array}{l}\text { Subsidiary } \\
\text { Roles/Tasks }\end{array}$ & & & & & & & \\
\hline $\begin{array}{l}\text { Non-subsi- } \\
\text { diary Roles/ } \\
\text { Tasks }\end{array}$ & & & & & & & \\
\hline
\end{tabular}

war on terror has also challenged the armed forces' previous status as the primary organization capable of defending a state against external - terrorist - attacks. According to Edmunds, intelligence, border and police forces "may be more suited to meeting day-to-day operational challenges posed by international terrorism, and over the long-term the utility of the military in this role may be limited."11

While calls for a peace dividend put pressure on states to downsize their armed forces, the range and diversity of military commitments proliferated considerably because states did not have to focus purely on national defence. More emphasis on the war on terror and the deterrence of terrorist threats led to the increased importance of armed forces and increased defence spending (mainly in the US). National security priorities included the need to be prepared to prevent, deter, coerce, disrupt or destroy international terrorists or the regimes that harbour them and to counter terrorists' efforts to acquire chemical, biological, and radiological and nuclear

9 The matrix was developed by the authors for a comparative assessment of non-traditional roles and tasks of armed forces in Western Europe and North America.

10 PMSC: Private Military and Security Companies.

11 Ibid., p. 1064. weapons. Multilateral peace and stabilisation operations as well as defence diplomacy were seen as important assets in addressing the causes and symptoms of conflict and terrorism. ${ }^{12}$ Numerous crises of a wider range and in a wider geographical area - ranging from Kosovo to Macedonia, Sierra Leone, East Timor, Afghanistan, Democratic Republic of Congo and Iraq demonstrated that the global security environment was as uncertain as ever and armed forces faced an even broader range, frequency, and often duration of tasks than previously envisaged. ${ }^{13}$

The new international security environment was seen as characterized by different security threats and risks: Future warfare was expected to be asymmetric, with non-state entities as the main adversaries. A 'broad arc of instability' across the 'Broader Middle East' - reaching from the Middle East to Northeast Asia - was identified as a key international security focus, as non-state entities whose activities were damaging Western and global security interests (such as drug traffickers or terrorists) were growing in strength and

\footnotetext{
12 Delivering Security in a Changing World: Defence White Paper, London: UK Ministry of Defence, 2003, p. 3.

13 Ibid., pp. 6-7.
} 
finding safe-havens in weak and failing states. ${ }^{14}$ In addition, new technologies (especially information technologies and those related to chemical, biological, radiological, nuclear, or enhanced high-explosive weapons) were seen to be increasingly within the reach of potential adversaries, while warfare would extend to space and across cyber space. 15 'New' threats were seen to include ethnic and religious conflict; population and environmental pressures; competition for scarce resources; and drugs, terrorism and crime, which are pressures that act both within states and across borders. The promotion of international stability, freedom and economic development were considered even by defence ministries as preferred methods to counter those threats. ${ }^{16}$

As shall be discussed in more detail below, the armed forces of many countries have been facing a myriad of new challenges, triggering tasks and roles beyond the core functions of national defence. Thus, "a number of different patterns and trends are emerging, all of which suggest important changes in how, and why, armed forces are used. Broadly, these are: the changing nature of the role of defending national territory; the appearance of new expeditionary roles, including warfighting and peacekeeping; the changing nature of internal security roles; and the continued saliency of nation-building and domestic military assistance roles."17

Those emerging non-traditional roles of armed forces, as the brief examinations below show, are diverse, evolving and do not seem to follow a particular logic even across the very small sample of countries referred to in the discussions countries that do reflect similar standards of political and security governance and are operating in a very similar security environment. Such variations can be expected to increase for examinations of contexts beyond Western Europe. Applying the research method of structured comparison, the matrix suggested below is meant to facilitate a meaningful analysis of the historical, political, economic, social and other factors that characterise multiple countries' approaches to their armed forces' place in society and evolving non-traditional roles inside and outside national borders.

As an illustration of the utility of this approach the following brief discussion focuses on international and domestic roles and tasks, including but not further developing non-military, military, subsidiary and non-subsidiary roles. These categories of non-traditional tasks will be examined in the context of subsequent project publications. On the horizontal axis, all factors besides the 'impact on accountability, objectives, command and traditional roles' will be addressed either explicitly or implicitly.

14 See, for instance, Judy Chizek, "Military Transformation: Intelligence, Surveillance and Reconnaissance", CRS Report, January 2003, available at: <http://www.fas.org/irp/crs/RL31425.pdf>, p. 6.

15 See Finnish Defence Policy 2001, available at: <http://www.defmin.fi/ files/1149/InEnglish.pdf >, p. 12; and Chizek, "Military Transformation", p. 6.

16 See, for instance, Strategic Defence Review, London: UK Ministry of Defence, 1998, art. 11, 29-30.

17 Edmunds, p. 1065.

\section{Comparative review of evolving non- traditional roles and tasks}

The core functions, responsibilities and competencies of armed forces, which continue to be of great significance for their ability to perform both traditional and non-traditional roles, include those related to self-defence; military defence of the territorial integrity of the state and the inviolability of its borders; actions aimed at guaranteeing the freedom of citizens and inviolability of state borders; and the promotion of international rule of law. ${ }^{18}$ They have developed as a consequence of the "fluid organizational milieu... [that caused] the emergence of a number of functionally diverse, organizationally fragmented and sometimes contradictory roles for European armed forces ... [while] socio-political influences have been the most important factors in determining the nature of and balance between these emergent new roles." 19 The following section provides a review of non-traditional international and domestic roles that have emerged in a number of Western European democracies.

\subsection{International roles}

International roles of armed forces include assistance in postconflict reconstruction; enforcement of economic sanctions and maritime intercept operations; the enforcement of exclusion zones; ensuring freedom of navigation and overflight; counter-insurgency support; non-combatant evacuation operations; protection of shipping and anti-piracy missions; and recovery operations. Crisis management activities abroad encompass a wide array of activities, including traditional peacekeeping functions such as monitoring of cease-fires; complex peace operation tasks that range from peace enforcement to post-conflict peacebuilding, including such tasks as institution building, development of infrastructure, support for the rule of law and good governance, or security sector reform (SSR) and disarmament, demobilisation and reintegration (DDR) programmes; as well as the protection and provision of humanitarian aid deliveries and close cooperation and protection of civilian aid organizations. New roles include assistance in cases of natural disasters or humanitarian catastrophes abroad; and disaster relief operations, including advice to civilian authorities, rescue missions and the provision of evacuation assistance in the case of biological disasters. Finally, armed forces are tasked to contribute to the control of the proliferation of arms, such as by seizing weapons of mass destruction, escorting authorised deliveries of weapons, or dismantling, destroying or disposing of weapons and hazardous

18 The legal basis for those roles is usually enshrined in the constitution of a country, or through specific legal provisions or decrees. See, for instance, Poland (Art. 26 of the Constitution), Spain (Art. 8 of the Constitution), Netherlands (Art. 97 of the Constitution), Italy (Art. 52 of the Constitution), Switzerland (Art. 58 of the Constitution); Germany (Art. 87a of the Basic Law), Belgium (1994 Royal Decree on Operational Engagement of Military Forces), Italy (2000 Law on the Rules for the Institution of the Professional Military Service), Luxembourg (1997 Law on Armed Forces), France (1959 Ordinance 59-147, "portant organisation générale de la défense"), UK (2001 Ministry of Defence Expenditure Plan and Main Estimates, pp. 5-6, The Role of the Ministry of Defence and the Capabilities of the Armed Forces).

19 Edmunds, p. 1075. 
material, all of which help reduce threats to regional and broader international security.

Those roles and tasks are defined differently in each country. For instance, Belgium's armed forces are expected to assist in observation missions abroad - where troops control the implementation of agreements, conventions, or agreed cease-fires, with the consent of all parties concerned; in protection missions - military operations aimed at protecting people in order to secure their safety and free movement; and the evacuation of Belgian nationals abroad; passive armed engagement - which are operations abroad that protect public order or peace, guarantee the respect for agreements and conventions, and prevent conflicts; including active armed engagement - operations conducted abroad where troops have to control violence or impose cease-fires, if necessary by the use of force. ${ }^{20}$ France's armed forces engage in civil-military actions abroad - missions to benefit the forces and the civilian population, or humanitarian missions (while the latter can be carried out in cooperation with civilian aid organizations); in crisis management abroad - aimed at protecting the vital interests of France, to contribute to the security and defence of Europe and the Mediterranean, and contribute to actions conducive to peace and the respect of international law; in the evacuation of nationals; and in the maintenance of public order. ${ }^{21}$ Spanish troops are involved in the maintenance of peace and international security - through crisis management, humanitarian aid and evacuation; and in the participation of operations undertaken jointly with the armed forces of other states. ${ }^{22}$ The British Armed Forces can be deployed to prevent conflicts and build stability; resolve crises and respond to emergencies; and to assist humanitarian aid operations. ${ }^{23}$

In summary, international roles of armed forces cover a wide range of old and new non-traditional tasks. While they vary from country to country, crisis management activities feature very prominently on the international task list of armed forces, partly as a result of the increasing engagement of the UN, regional organizations or military alliances in peace missions abroad. International peace operations are emerging as regular activities of armed forces around the world, unintentionally creating a new, global military esprit de corps and an initial semblance of global, supranational security provision.

\subsection{Domestic roles}

Domestic roles of armed forces include the replacement of vital services during industrial action (strikes or labour movements disrupting economic activity); education of civilians (youth re-education centres or specialized training centres); cartographical and meteorological services; road and

20 See 1994 Royal Decree on Operational Engagement of Military Forces; 1994 Law on Armed Forces.

21 See 1997 Directive on Civil-Military Actions; Ordinance No. 59-147 from January 1959; Decree No. 95-573 from 2 May 1995 on Military Assistance in Maintaining Public Order; 1995 Inter-ministerial Instruction Military Assistance in Maintaining Public Order; 2008 French White Paper on Military Strategy and National Defence.

22 See "Royal Ordinances" approved by Law 85/1978; Art. 94 of the Constitution.

23 See 2006 Armed Forces Act; 1996 Reserve Forces Act; 1989 Manual of Military Law Part II. infrastructure construction, improvement and engineering; assistance to public administration and the population in case of force majeure (the occurrence of a major industrial incident, massive terrorist attack, or sanitary crisis following a major disaster) or natural disasters. They include search and rescue operations; law enforcement; environmental protection; medical support for poor communities; support of training and education opportunities for disadvantaged youth; border surveillance; provide support and security of supplies (in reference to food, energy, transport, storage, distribution networks and information systems); or security provision during major public events (international sport championships or major global conferences). They further encompass counterterrorism - offensive and defensive measures to prevent, deter or respond to terrorist activities; anti-smuggling and antitrafficking operations; counter-drug operations - detecting and monitoring aerial and maritime transit of illegal drugs; integrating the command, control, communications, computer, and intelligence assets that are dedicated to interdicting the movement of illegal drugs; supporting drug interdiction and enforcement agencies; and humanitarian aid at home. Many of those tasks are subsidiary ones performed under the command of other security institutions' activities.

For instance, in Belgium these roles translate into tasks for armed forces that include assistance to the civil population; maintenance of public order; or humanitarian assistance and relief assistance in cases of natural disasters and at times of terrorist attacks. ${ }^{24}$ In France such domestic tasks include civil-military actions at home - missions to benefit the forces, missions to benefit the civilian population and humanitarian missions (while the latter can be carried out in cooperation with civilian aid organizations); civil defence - responses to national catastrophes and the preservation of public order; counter-terrorism operations; and involvements in other 'states of urgency'. ${ }^{25}$ In Spain armed forces provide civil defence and intervention in cases of emergency and in counter-terrorism operations. ${ }^{26}$ In the UK domestic tasks include restoration of public security, internal emergency and natural disasters. ${ }^{27}$

Armed forces are thus called upon to assist in domestic security provision in situations that require exceptional efforts to respond to exceptional situations - natural or humanitarian catastrophes that exceed civilian security institutions' capacity. At the same time, as those situations rarely arise, it makes little sense for civilian security institutions to prepare at great cost for such unusual occurrences, while alternative capacities are in easy reach. Under the command and control of civilian agencies, the usually subsidiary operations by armed forces are meant to enhance the capacity of civilian security providers when asked to assist in extraordinary situations.

241994 Royal Decree on Operational Engagement of Military Forces; 1994 Law on Armed Forces.

25 See 1997 Directive on Civil-Military Actions; Ordinance No. 59-147 from January 1959; 1983 Decree No. 83-321 on the Prerogatives of Prefects in Terms of Non-military Defense; Ministerial Instruction from 7 February establishing the SGDN; Ordinance 60-372 from 15 April 1960 on the state of Urgency; Inter-Ministerial Instruction No. 500/SGDN/MTS/OTP of 9 May 1995 on the Participation of the Military in Maintaining Public Order.

26 See Royal Decree 1125/1976, Organic Law 4/1981 on the Declaration of Emergency, Law 2/1985 of 21 January 1985 on Civil Protection.

27 See 1920 and 1964 Emergency Powers Acts. 


\subsection{Utility and motivations to engage in non- traditional roles}

Why do armed forces become involved in non-traditional tasks? What are the motivations for seeing the state's armed forces move beyond core functions of national defence? While a thorough assessment of motivations needs to compare and distinguish between congruencies and variations of motivations as expressed by governments, the armed services themselves as well as broader public opinion, the following are some of the key reasons that have been mentioned as the driving forces for increasingly prominent international and domestic non-traditional roles and tasks. ${ }^{28}$

In international roles, these include a sense of responsibility to alleviate human suffering caused by conflict; commitments made through international treaties and obligations, as well as through membership in regional collective/cooperative security organizations and the UN; international, regional and national security concerns caused by the potential for unstable and conflict-affected states to become bases for terrorist activity and international crime as well as sources of refugee flows; and the conviction that the special equipment, skills and operational capacity of armed forces give it a comparative advantage over all other national, international or nongovernmental public (or private) service providers in offering quicker and more effective responses to situations of disaster abroad. In domestic roles, these include the need to help out with the delivery of services that are normally provided by civilian public services and government agencies, but are temporarily unavailable; the ability of armed services to provide a unifying mechanism that reaches across all communities and classes of society and is thus able to impart a unique sense of national conscience and patriotism particularly among the youth; the armed forces' possession of the proper equipment, skills, experience as well as unhindered territorial access to all parts of the country; as well as new requirements for internal security provision generated by the nature and methods of counter-terrorist activities related to homeland security and the 'war on terror.'

\subsection{Competitors for non-traditional roles: police and paramilitary forces}

Not only do armed forces 'intrude' into the priority areas of other security institutions within the security sector, but in particular police and paramilitary forces (among other security sector institutions, such as border guards, intelligence services,

28 For further discussions on the utility and motivations to engage in nontraditional roles, see Juan G. Ayala, "What Else Should Our Military Forces Be Doing? The Benefits of Participating in Military Operations Other Than War", Newport, RI, Naval War College, 2000, available at: <http://handle.dtic. mil/100.2/ADA381713>; Nogues Thierry Chevrier and Stéhane Sauvage André, "Armées et sécurité intérieure: Perception des acteurs institutionnels civils et militaire", LARES-Université Rennes 2-C2SD, May 2001, available at: <http:// www.c2sd.sga.defense.gouv.fr/IMG/pdf/armee_securite_int_10_01.pdf>; Michiel de Weger, "De binnenlandse veiligheidstaken van de Nederlandse krijgsmacht", Van Gorcum, 2006; Nogues Thierry, "Armées et missions de sécurité intérieure", Doctrine, No. 6, March 2005, available at: <http://www. cdef.terre.defense.gouv.fr/publications/doctrine/doctrine06/version_fr/ libre_reflex/art_17.pdf $>$. Subsequent publications on the methodology and findings of this project will further distinguish between motivations of various key stakeholders, also in the specific context of military, non-military, subsidiary and non-subsidiary tasks. private military and security companies, or the judiciary) are also taking on roles previously - or in other countries - reserved for the armed forces. ${ }^{29}$ Research on the division of labour between those security institutions, as well as the reasons for evolving shifts in that division of labour, will be helpful in developing common approaches that are sensible and draw on the real comparative capabilities of a variety of other, sometimes competing, institutions within the same security sector. The following are some examples of police and paramilitary roles in functions that could be - and in other countries still are considered to be prerogatives of the armed forces.

In Belgium the Chief of the Federal Police is allowed to request the assistance of the armed forces in situations of urgency to keep the public peace and restore order, an example for armed forces' subsidiary domestic tasks performed under the authority of a requesting civilian authority. ${ }^{30}$ In Spain the police engage in border control, immigration control, investigation of drug related crimes, control of private military and security companies, as well as cooperation with other national police forces. ${ }^{31}$ The Spanish Guardia Civil is tasked with a wide variety of security roles, including the maintenance of public order; prevention and investigation of crimes; prevention of criminal acts; ensuring the safety of goods and persons; law enforcement; protection of public buildings and installations; as well as collaboration with civil protection units in cases of grave risks, catastrophes or disasters; counter-trafficking activities; ensuring the security of various infrastructure and communication networks, ports, airports and borders; intercity transportation of prisoners; and the protection of natural resources. ${ }^{32}$ France provides for the National Gendarmerie to be deployed in missions abroad, and at home it allows for the gendarmerie to ensure public order especially in the rural areas, to gather information and intelligence on counter-terrorism, and to ensure the protection of the nuclear armament of the country. ${ }^{33}$

The armed forces are not the primary security providers within a country's security sector. At home they are secondary security providers to be called upon under exceptional circumstances, when police or paramilitary forces are not in a position to respond adequately to a particular security challenge. Yet, paramilitaries have been created precisely because certain challenges require more than what the police can offer, but less than a military response would entail. Assessing the comparative advantages of paramilitary forces vis-à-vis police and armed forces, at home and abroad, will help explain the utility of maintaining these forces as separate entities, rather than investing in the creation of military units trained in, for instance, crowd control or police forces equipped and trained

29 Heiner Hänggi, "Making Sense of Security Sector Governance", in Heiner Hänggi and Theodor Winkler, eds., Challenges of Security Sector Governance, Münster: LIT, 2003. For a recent account of security sector reform and governance, as well as their implementation in real world environments, see Hans Born and Albrecht Schnabel, eds., Security Sector Reform in Challenging Environments, Münster: LIT, 2009.

301999 Law on Federal Police.

31 Organic Law 2/1986 on Security Forces.

32 Law 42/1999 regulating the statute of the Guardia Civil, Organic Law 2/1986 on Security Forces, Organic Law 11/1991 on the Disciplinary Regime of the Guardia Civil.

33 See Law 2009-971 from 3 August 2009 relative to the Gendarmerie Nationale. 
for major disaster response and what could be called domestic 'muscular law enforcement' or counter-insurgency action.

\subsection{Opportunities and threats of non-traditional roles and tasks}

Non-traditional roles imply numerous opportunities to prove the usefulness, purpose and comparative advantages of the armed forces vis-à-vis other security providers, even (or particularly) in political environments that are less prone to the necessity to defend state and society from military attacks by external actors. Of course, expanding - possibly overstretching - one's roles and capabilities into areas previously held exclusively by civilian actors or other security institutions also carries some dangers. Both opportunities and dangers will be briefly examined in the following paragraphs.

Opportunities of the expansion of the armed forces' prerogatives include its support of the state's capacity to defend against external threats without having to rely on outside actors and their assistance; it enhances a state's projection of regional and international political and military clout; and it strengthens the capacity to contribute to regional and international security and thus helps solidifying the state's role as a regional and international 'player'. Especially in the cases of small and middle powers the ability and willingness to contribute to international peace operations even through small military and civilian contributions enhance the state's international prestige and allow it to make significant contributions to the preservation of international security. At the same time, participation in international peace operations puts armed forces under pressure to develop relevant non-military skills and capacities to operate in complex, multi-sectoral and multiactor settings, and to gain experience in 'real-life' missions. Support for UN missions enhances a state's reputation as an international team player who is able to promote a climate of peaceful cooperation, thus promoting regional and international political stability.

Domestically, opportunities of an expansion of the armed forces' prerogatives include the ability to resolve extraordinary national crises that could otherwise not be resolved without outside assistance; to maintain an independent domestic capacity for anti-terrorist and counter-insurgency warfare; and to deter nonstate armed challengers of domestic and regional security and stability. As a result, the armed forces and government authorities are in a position to send clear signals to the taxpayers and their political representatives that they are able to make important peacetime contributions to the safety and security of society, even in the absence of an external threat. This translates into an appreciation of the armed forces' worthiness of public financial contributions during times of peace and conflict. Moreover, by utilizing special skills, equipment and organizational culture, the armed forces are able to address domestic security risks and threats and offer capacities for disaster response not otherwise available through domestic means and actors. Civilian organizations are therefore spared the need to develop and maintain capacities to deal with extraordinary crises. At the same time there is less pressure on the armed forces to reduce their own capacities and the government is in a more favourable position to withstand public and political pressure to cut peacetime defence budgets.

There are also risks and threats related to the expansion of the armed forces' prerogatives: By moving away from military core functions - including in education and training - some fear an erosion of the armed forces' preparedness to fulfil their core tasks. Requirements for specialized training for peace operations are feared to divert skill-sets away from the core focus on national defence, while governmental and nongovernmental aid and development organizations are considered to be better suited for tackling the complex peacebuilding roles that troops are increasingly asked to perform. Thus, there is a fear that armed forces might be confronted with challenges for which they are not prepared and which will consequently only hurt their reputation abroad and at home. Proper preparation would thus require thorough reforms of potentially unsuitable organizational structures, along with additional training and equipment. However, adjusting existing structures, training and equipment to new tasks is in turn again seen as undermining the armed forces' core tasks.

Threats and risks of granting the armed forces a more prominent internal role include the fear of losing civilian control over the armed forces; the military establishment's potential assertion of a greater role and influence in society and politics, thus continuing the erosion of the principle of separating civilian and military authority; ${ }^{34}$ the creeping militarisation of civilian technical tasks, civilian partners in subsidiary missions and the population overall; the militarisation of genuine policing tasks, of the justice system and penal institutions; and potential losses of public finances and personnel among civilian institutions. Similar to expanding the armed forces' international roles, strengthening their domestic footprint also raises the risks of eroding preparedness for core functions of national defence and war-fighting abilities, and an overall sense that deficient skills for domestic tasks might hinder effective and thus appreciated performance. ${ }^{35}$

\section{Conclusion: Towards comparative lessons from armed forces' evolving non-traditional roles and tasks}

As was briefly demonstrated in the previous sections, the systematic analysis facilitated by the matrix introduced earlier in the article allows us to move from mere description (the main tenor of this article) to a comparative analysis of the congruencies and incongruencies (i.e. variation) between and within individual countries' approaches and experiences with evolving and shifting non-traditional roles of armed forces, the reasons and impact of those developments, as well as the lessons that might be drawn for security sector and defence reforms in different political and security contexts. The proposed matrix

\footnotetext{
34 See Keith Krause, "Towards a Practical Human Security Agenda”, DCAF Policy Paper, No. 26, Geneva: DCAF, 2007, pp. 11-15.

35 According to Huntington, for instance, additional tasks for the military should not impair the army's main mission, which is warfare. See Huntington, "New Contingencies, Old Roles".
} 
allows the study of single country contexts, comparisons between any two or more countries, or comparisons between the specific approaches of countries within a certain geographic region as well as a specific military alliance or collective/ cooperative security organisation. In addition, periodic assessments allow for longitudinal observations and analyses of developments and changes over time.

The analyses facilitated by such a systematic and structured comparison should prove useful for researchers who explore changing approaches to utilizing and projecting military power in national and international politics. They should moreover assist practitioners who might use the matrix as a decision and policy support tool to inform defence and security sector reform programmes both at home and abroad.

The results of such comparative analyses of armed forces' non-traditional roles and tasks will help us in identifying and understanding the changing purposes of armed forces in a world that is increasingly characterized by what one might call zones of 'new peace' (which are evolving from stable security communities ${ }^{36}$ ), zones of 'old wars' (countries and regions with recent or continuing threats of intra- and interstate armed conflict) and zones of 'new wars' (characterised by threats that range from new levels and dynamics of urban and other violent crime to the impact and dynamics of global terrorism). Moreover, such examinations might unearth intriguing dynamics of national conversations about a nation's involvement in securing, in the broadest sense of the term, societies and regions beyond its political and economic spheres of interest, thus operationalising a possibly growing sense of

36 Emanuel Adler and Michael Barnett, eds., Security Communities, Cambridge: Cambridge University Press, 1998. 'responsibility to protect' the human security of populations trapped in old and new wars. ${ }^{37}$

Analysing data collected with the help of this matrix should trigger further inquiries into contradictions and inconsistencies that are created within a nation's security sector in relation to evolving separations of tasks, competencies, responsibilities and authorities. On the other hand, useful lessons might be learned from those states whose security sectors have undergone both major and subtle shifts in the division of tasks linked to the provision of evolving perceptions of and approaches to security. How have the armed forces in countries where such shifts have taken place coped with these new challenges? To what degree have they coped with the need to develop new competencies, while losing others? How have they been able to embrace new non-traditional roles, while maintaining a sensible level of capacity and preparedness to face traditional threats with traditional approaches, if need be? Have additional roles for the armed forces been accommodated in terms of accountability (such as civilian oversight) and command structures? How did the public accept or oppose these extended roles of the armed forces? Of course, the matrix needs to be adapted to be able to chart and analyse the existing and evolving roles of armed forces in countries outside Western Europe. The findings could be of significant value to those states (and relevant security sectors) that are in the process of redefining and recalibrating the roles of their armed forces - and, by necessity, the entire security sector - in response to evolving national and international security realities.

37 International Commission on Intervention and State Sovereignty, The Responsibility to Protect: Report of the International Commission on Intervention and State Sovereignty, Ottawa: International Development Research Centre, December 2001.

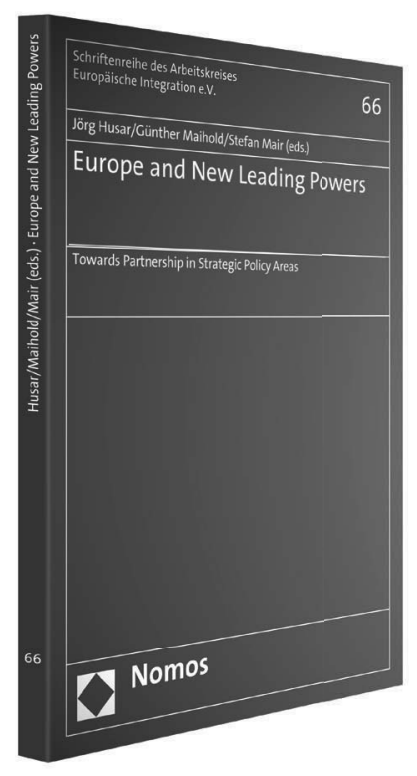

\section{Europe and New Leading Powers}

Towards Partnership in Strategic Policy Areas

Edited by Jörg Husar, Günther Maihold and Stefan Mair

2010, 157 pp., pb., € 29.00, ISBN 978-3-8329-5590-8

(Schriftenreihe des Arbeitskreises Europäische Integration e.V., vol. 66)

In an increasingly multipolar world order, the EU needs to enhance its relations with secondary powers (beyond the $\mathrm{G} 8$ ) that exert influence at the regional and global level. Since strategic partnerships with these "New Leading Powers" have proven insufficient, this book explores policy area specific partnerships as an instrument of European foreign policy. \\ Nomos}

